\title{
Knowledge and Attitudes Toward Premarital Sex Behavior Students of SMAN "X" Jakarta
}

\section{Sri Rahayu Kadarwati, C. Endah Wuryaningsih, and M. Alaydrus}

Faculty of Public Health, Universitas Indonesia, Depok, Indonesia

\section{Abstract}

Teenager is a period of transition from childhood to adulthood. Natural changes in adolescents have an impact on adolescent problems are severe enough, one of which is premarital sex. Many teenagers have premarital sex without realizing the direct and indirect result of self and partner. SMAN " $X$ " Jakarta, located in the center of the crowd and shopping centers Blok $\mathrm{M}$, where there is a flow of information rapidly and socio-cultural changes are also relatively fast, with such conditions may occur behavior are varied, both positive and negative behaviors/deviant behaviors such as premarital sex. This study aims to describe the characteristics, knowledge, and attitudes toward premarital sexual behavior of students of SMAN "X" Jakarta. The cross-sectional

Corresponding Author: C. Endah Wuryaningsih caroline2ew@yahoo.com

Received: 26 December 2018 Accepted: 23 February 2019 Published: 7 March 2019

Publishing services provided by Knowledge E

(c) Sri Rahayu Kadarwati et al. This article is distributed under the terms of the Creative Commons Attribution License, which permits unrestricted use and redistribution provided that the original author and source are credited.

Selection and Peer-review under the responsibility of the $2 \mathrm{nd}$ International Meeting of Public Health 2016 Conference Committee.

\section{G OPEN ACCESS} research involved 106 respondents take by simple random sampling. The results showed that the majority of respondents have knowledge about sexuality, particularly premarital sex, is good (61.3\%), the most substantial proportion of the respondents' attitudes were positive (55.7\%), while the spread of sexual behavior is sexual behavior by weight (71.7\%). From the results of the bivariate analysis, it known that there is a significant relationship between sex, knowledge, and attitudes to premarital sexual behavior. Based on the results, it is essential coaching (through counseling, training, and extracurricular activities) of adolescents about reproductive health issues, especially sexuality, to remind teenagers, in particular, has high school teenagers always to be vigilant and avoid deviant behaviors such as premarital sexual behavior.

Keywords: teenagers; knowledge; attitudes; premarital sex behavior

\section{Introduction}

Indonesia as a developing country has a population of adolescents' old sizeable structure of the society of Indonesia. The data from BPS (2002), says that the age group of $10-24$ years and premarital is amounting to 62 million people (30.3\%) of the total population of Indonesia. Thus adolescents need to receive adequate attention from the government, community, and family.

One of the major problems faced by adolescents is the adjustment to the physiological and psychological changes due to the influence of reproductive hormones that have 
started functioning. After gaining experience of first menstruation (menarche) for women and the first wet dream (Pollution) for men accompanied by the function of reproductive hormones; and psychological changes happen to like change in the way of thinking, emotions, personality, and values (moral, social, etc.), making knowledge on issues surrounding sexuality and the desire to flow the sexual drive becomes larger.

From the research done by Demography Institution of FE-UI, it found that $4 \%$ of teens said they had sexual intercourse before marriage, which is $5 \%$ of adolescents' cities and $3.3 \%$ of the village youth. Furthermore, by sex, $4.7 \%$ of young men and teenage girls stated that they had sexual intercourse before marriage. The results based on gender illustrates that boys have a higher percentage than the adolescent girls in sexual intercourse. The occurs because young men are more open about sexual problems than girl's adolescent. And sexual activity begins or initiated by men, then the women followed or as sexual objects only.

The teens of Senior High School (SMU) also included within the scope of adolescents aged of 15-19 years old whereas previously described only in this age are the most vulnerable period in human life, which at this time may have happened both physical and psychological changes and if not accompanied by the readiness of the youth to face the difference is not likely to lead to deviant behavior that would harm the adolescents themselves.

One Senior High School is SMAN " $X$ " locates in South Jakarta, which also close to the center of the crowd and shopping centers of Blok $M$, where there is a flow of information rapidly and where the socio-cultural changes are also relatively fast, so with such conditions may occur varied behaviors, both positive and negative deviant behavior such as premarital sexual behavior. Based on that, the research question arises how much are knowledge and attitudes about premarital sexual behavior.

\section{Method}

The is a quantitative study with a cross-sectional design study, due to the measurement of independent variables with the dependent variable done at the same time - the survey conducted in SMAN "X" Jakarta as a place where public education with the students who are in the age group between 14-19 years old. The is consistent with the purpose of the study to describe the level of knowledge and attitudes toward premarital sexual behavior of teens.

This study conducted on teenagers from the Senior High School students in grade 2. The total population of this research consists of 398 students, divided into ten classes. Samples of this study take by using a proportional way, namely by stealing from each 
level randomly. Minimum sample size made in this study is calculated as the estimated equivalent simple random sample (Lemeshow et al. 1997).

From the calculation results, it obtained a minimum sample size of 78 students. In anticipation of the respondents who are not willing to fill out a questionnaire and some who were being taking the exam remedy, as well as a survey that is damaged or does not qualify, then the researchers set the sample size in this study to 106 people of all students in grade of 2 SMAN "X" Jakarta.

The studied population is homogeneous, so the sampling is done by simple random sampling, in which all individuals have equal opportunity elected as the sample (Anwar 1987).

The data used in this study uses primary data and secondary data, primary data was taken from direct sources, collected through a questionnaire, and filled directly by the cause (the respondent) - secondary data obtained from the School of Business Administration, in the form of a list of names of students selected for the study and other data that already exists and needed in this study. The research instrument taken by using a questionnaire, the questionnaire was given to respondents to be filled directly without going through the interview process.

After correction and improvements of the contents of the questionnaire, and then conducted taking of a sample in the field. Sampling was done during school hours of BK (Guidance and Counseling).

Data analysis is a significant activity in a study for the review because of this analysis the data may have a meaning/significance that can be useful for solving research problems. In this study, the report uses univariate and bivariate analysis.

Confidence level used is $95 \%(\alpha=0.05)$, if the $p$-value less than $\alpha(p<0.05)$, meaning that there is a significant relationship (significant of the two variables being study). If the $p$-value is greater than $\alpha$ ( $p>0.05)$, meaning that there is no significant relationship between the two variables being studied.

\section{Results}

In Table 1 we can see the relationship between knowledge and premarital sexual behavior. Respondents who know of "good," $13.8 \%$ fall into the category of "never," $7.7 \%$ in the category of premarital sexual behavior, "light," and 78.5\% included in the category of sex before marriage "heavy." For respondents with the level of knowledge "less," $61 \%$ included in the category of premarital sexual behavior "heavy," $26.8 \%$ in the category of "light" and the remaining $12.2 \%$ in the category of "never." Bivariate test results suggest 
that there is a significant correlation of knowledge about premarital sex and adolescent premarital sexual behavior $(p=0.027)$.

TABLE 1: The Relation of Respondent Knowledge On the Premarital Sexual and Premarital Sexual Behavior of Student Class 2 SMAN "X" Jakarta.

\begin{tabular}{|c|c|c|c|c|c|c|c|c|c|}
\hline \multirow[t]{3}{*}{ Knowledge } & \multicolumn{6}{|c|}{ Premarital Sexual Behavior } & & & \multirow[t]{3}{*}{ p value } \\
\hline & \multicolumn{2}{|c|}{ Never } & \multicolumn{2}{|c|}{ Light } & \multicolumn{2}{|c|}{ Heavy } & \multicolumn{2}{|c|}{ Total } & \\
\hline & $\mathbf{N}$ & $\%$ & $\mathbf{n}$ & $\%$ & $\mathbf{N}$ & $\%$ & $\mathbf{n}$ & $\%$ & \\
\hline Less & 5 & 12.2 & 11 & 26.8 & 25 & 61 & 41 & 100 & \\
\hline Good & 9 & 13.8 & 5 & 7.7 & 51 & 78.5 & 65 & 100 & 0.027 \\
\hline Total & 14 & 13.2 & 16 & 15.1 & 76 & 71.7 & 106 & 100 & \\
\hline
\end{tabular}

TABLE 2: The Relation of Respondent Attitude on Premarital Sex and Sexual Behavior of Prenuptial on Students Class 2 SMAN “X” Jakarta.

\begin{tabular}{|c|c|c|c|c|c|c|c|c|c|}
\hline \multirow[t]{3}{*}{ Behavior } & \multicolumn{6}{|c|}{ Premarital Sexual Behavior Pra-Wedding } & & & \multirow[t]{3}{*}{ p value } \\
\hline & \multicolumn{2}{|c|}{ Never } & \multicolumn{2}{|c|}{ Light } & \multicolumn{2}{|c|}{ Heavy } & \multicolumn{2}{|c|}{ Total } & \\
\hline & $\mathbf{N}$ & $\%$ & $\mathbf{n}$ & $\%$ & $\mathbf{N}$ & $\%$ & $\mathbf{n}$ & $\%$ & \\
\hline Negative & 6 & 12.8 & 2 & 4.3 & 39 & 83 & 47 & 100 & \\
\hline Positive & 8 & 13.6 & 14 & 23.7 & 37 & 62.7 & 59 & 100 & 0.018 \\
\hline Total & 14 & 13.2 & 16 & 15.1 & 76 & 71.7 & 106 & 100 & \\
\hline
\end{tabular}

In Table 2, it can be seen that the relationship between attitudes toward premarital sex with adolescent premarital sexual behavior. For the highest proportion found in premarital sexual behavior of respondents is heavy, as being (negative) that is $83 \%$, while being (positive) is (62.7\%). The result of bivariate analysis suggests that there is a significant relationship between attitudes toward premarital sex with adolescent premarital sexual behavior $(p=0.018)$.

\section{Discussion}

Sexual intercourse among adolescents has become one that is not exceptional anymore. Most who do not want to have sexual intercourse, have a particular reason, namely the fear of losing virginity, fear of pregnancy, and feel guilty, but instead of the sexual relationship, they want to do other sexual activities that also provide sexual satisfaction. Furthermore, sexual relations increasingly tend to be free, take place not only with one partner but more than one, by the principle of "consensual" (Pangkahila 1998).

The results of the study show that the most significant proportion of respondents included in the category of "heavy" (71.7\%) and the smallest proportion of respondents included in the category of "never" (13.2\%). 
In essence, of the sexual problems in this age group come from changes in organ biologics due to the maturation of the reproductive organs of teens where girls will get their period which marks that the body was unable to conceive, while men will experience a wet dream as a sign that he can produce sperms and ejaculated.

Sexual activity conducted by respondents included in the category of "heavy" is the highest proportion of kissing lips (75\%), then fingered sensitive limbs, and attached genitals have the same proportion, namely (44.8\%) and the smallest proportion of the activity of sexual relationship (9.4\%). Through this study, it can know that of 106 respondents there are 76 respondents (71.7\%) with sexual activity of "heavy." In this study, it is known that of the 106 respondents, 9 (8.5\%) have had sexual intercourse before marriage. This amount is still more significant when compared to the research conducted by Yuyun (2003) in the second grade of Senior High School students in the city of Bogor in 2003; the result is only 7 (1.5\%) of 476 respondents.

In this study, respondent' knowledge about premarital sex measured from the 22 questions contained in the questionnaire with a median value of 15. Respondents who obtain a score greater than or equal to the median value of knowledge categorized as "good," in contrast to respondents who have scored less than the median value categorized as "less."

The results of the knowledge show that there are 65 respondents (61.3\%) included in the category of "good" and 41 respondents (38.7\%) included in the category of "less." In this study does not prove that good knowledge generates good premarital sexual behavior too. Because of 65 respondents who have "good" knowledge, there are 51 people (78.5\%) of heavy premarital sexual behavior. While 41 respondents who have "less" knowledge there are 25 people (61\%) of heavy premarital sexual behavior. The test results bivariate analysis shows that there is a significant relationship between knowledge and premarital sexual behavior $(p=0.027)$. These results are consistent with the study of Yuyun (2003), which proves that there is a significant relationship between the level of knowledge with premarital sexual behavior $(p=0.021)$. At attitude measurement in this study, it used the category of "positive" and "negative" to assess the attitudes of each respondent. The result shows that most respondents (55.7\%) have a positive attitude and the remaining of $44.3 \%$ being negative. These results are consistent with the study of Gusmiarini (2010) on grade 2 students of SMU Purwakarta that the majority of adolescents (95.1\%) have a positive attitude towards premarital sex. The emergence of a positive attitude supported by a good enough knowledge about sexuality. It is also stated by Notoatmodjo (1993) that education is an essential element in the formation of a person's attitude. For the realization of a gesture into an act, it needs motivating factors or conditions to allow (Green 1980), because of external factors which adolescents 
affect the understanding of the attitude very much into behavior. The happens on the respondents, where the location of the school adjacent to the center of the hustle and shopping center of Blok $\mathrm{M}$, where access to activities as a teenager is possible to do, be it positive or negative, so it is not likely to happen to deviant behaviors, such as sexual behavior.

\section{Conclusion}

Based on the results of data analysis and discussion, it can be summarized in the conclusion that the highest proportion of premarital sexual behavior of students grade 2 SMAN "X" Jakarta are the respondents in the category of "heavy" (71.7\%) and the number of respondents in the category of "light" (15.1\%), while the lowest proportion of respondents are those included in the category of 'never' (13.2\%). Most respondents already have or are dating (90.6\%), and the rest have not been dating yet. Of the respondents who already have or are in dating, there are 9.4\% ever had sexual intercourse. In general, this number is still low, but this is quite alarming. From the side of gender, the number of women respondents is higher (55.9\%) compared with the number of male respondents (48.1\%). The largest age group is the late adolescent group (57.5\%), while the mid-teens (42.5\%), and the majority of respondents live with their parents (95.3\%). Respondents' knowledge about sexuality, in general, is good (61.3\%). The highest respondents' attitudes about premarital sex are on the respondents of "positive" attitude (55.7\%). This study shows that several variables significantly associated with premarital sexual behavior, namely gender $(p=0.043)$, knowledge $(p=0.027)$ and attitude $(p=0.018)$. To control the increase of a risk premarital sexual behavior to the students of SMAN " $X$ " Jakarta, it is necessary to done intervention measures on all factors that influence the behavior. For future studies, it would be better if the respondents' sexual behavior associated with respondents' sexual behavior at the time of the study, so it would be known more certainty whether sexual behavior is a past sexual behavior or sexual behavior when data collection is done.

\section{Acknowledgment}

Data guide this study.Endah Wuryaningsih, M.Kes., Drs. H.M Thahir Husein as Kepala Sub Dinas Pendidikan SMU (Head of Sub Education Office of Senior High School), Drs. H.Sidik Yasin, MM., as School Headmaster of SMAN "X" Jakarta for their approval to research SMAN “ $X$ ” Jakarta., Drs.Muchlis Alaydrus, teacher of Guidance and Counseling of class 2 SMAN " $X$ " and surveyor team in collecting research data. 


\section{References}

[1] Gusmiarini, Tri, 2000. Factors Associated With Teen Sexual Behaviour Grade 2 SMU Purwakarta. Thesis Faculty of Public Health

[2] Lemeshow, S, Hosmer, D, Klar, J, Lwanga, S. 1997. A sample in health research. Translation, Jogyakarta, Gadjah Mada University Press.

[3] Notoatmodjo, Kartono, 1998. Contradictions in Reproductive Health. Series of Reproductive Health, Culture, and Society. Pustaka Sinar Harapan Bangsa Cooperation with PT.Citra Son and The Ford Foundation, Jakarta.

[4] Pangkahila, et al. 1998. The frequency of sexual intercourse without condoms with female sex workers (FSW) is not related to the level of sexual satisfaction a married man but associated with the risk of sexually transmitted infections. Journal articles,

[5] Yuyun, Rani. 2003. Factors Associated With Teen Sexual Behavior Grade 2 Public High School Students In The City of Bogor. Thesis Faculty of Public Health. 